DOI: https://doi.org/10.47405/mjssh.v5i10.515

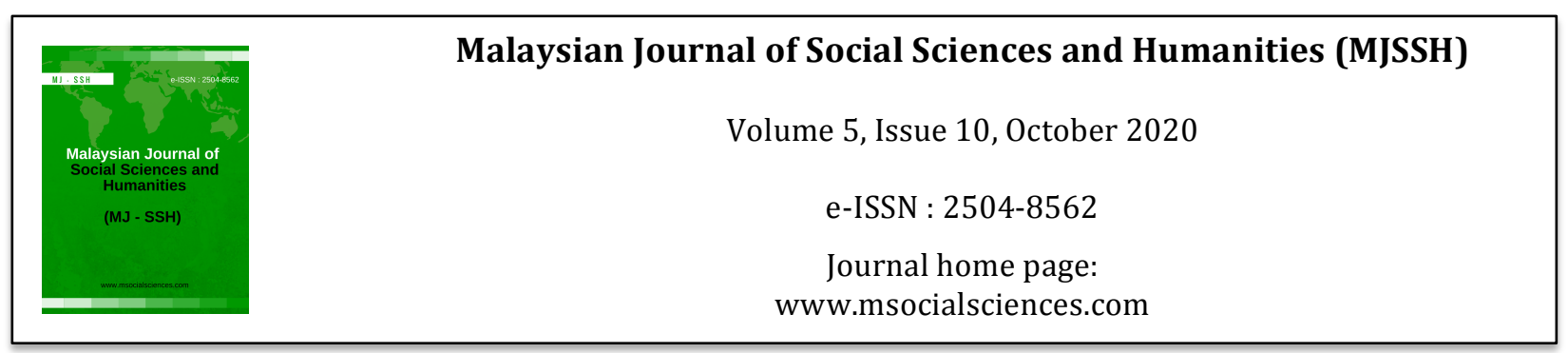

\title{
Education and Writing Culture in the Sultanate of Riau-Lingga During the Early Nineteenth Century
}

\author{
Hafiz Zakariya ${ }^{1}$, Wiwin Oktasari ${ }^{1}$ \\ ${ }^{1}$ International Islamic University Malaysia (IIUM) \\ Correspondence: Hafiz Zakariya (hafizz@iium.edu.my)
}

\begin{abstract}
Historically, the Riau-Lingga Sultanate (1824-1911), is renowned for its significant economic, political, and cultural contributions to the Malay world. It is home to prominent thinkers and writers such as Raja Ali Haji and the members of the Rushdiah club. The continuing cultural dynamism of the Sultanate of Riau-Lingga is an amazing story as it continued to grow despite the collapse of its political power and consequently the imposition of the Dutch control in the area. This study examines the growth and development of education, library and writing culture during the early nineteenth century. It employs the methods of historical research and textual analysis by examining the growth of these institutions within the historical contexts of the early nineteenth century.
\end{abstract}

Keywords: Riau-Lingga kingdom, education in Riau, library in Riau, writing culture

\section{Introduction}

Riau in the eighteenth century was the major entrepot on the sea route from India to China. The eventual political decline of this kingdom started when it launched a failed attack on Dutch-controlled Malacca in 1784. Consequently, Riau increasingly succumbed to the Dutch power and in 1830 Dutch officially established its control over Riau. Despite its political decline, Riau continued to flourish intellectually. It served as a prominent literary, cultural, and religious center in the Malay world. During the second half of the nineteenth century, it produced prominent thinkers and writers such as Raja Ali Haji (ca. 1809-1870). Moreover, Riau was a convenient stopover for religious scholars and pilgrims traveling from the Middle East to the Malay world as the royal family had been renowned for its patronage of religious scholars and Islamic activities. This article discusses the development of education, library and writing culture in Riau during the early nineteenth century.

\section{Problem Statement and Methodology}

This study examines the advent and growth of Islam, education and writing culture in the Riau-Lingga kingdom during the early nineteenth century. Its main objectives are as follows:
i. To explain a brief history of the Riau-Lingga kingdom.
ii. To discuss the advent and growth of educational institutions in the kingdom.
iii. To analyse the growth of writing culture in the kingdom. 
To accomplish its objectives, this study adopts the methods of textual analysis and historical research through a critical examination of the primary source materials. The major primary sources used in this study are manuscripts at Penyengat Island. Besides, authoritative secondary sources on the subject have also been critically examined.

\section{Historical Background of Riau-Lingga}

The Riau Islands Province consist of the Riau Archipelago, the Tujuh Archipelago (i.e., the Badas Islands, the Tambelan Islands, the Natuna Islands, and the Anambas Islands), and the Lingga Islands. Following the Anglo-Dutch Treaty of 1824, the Riau-Lingga Sultanate was separated from the Johor Sultanate. During that time, Daik functioned as the seat of Sultanate of Riau-Lingga, Penyengat Island as the Yang Dipertuan Muda's seat, and Tanjung Pinang as the base of the Dutch authority. Historically, under the Johor Sultanate, Singapore (Temasek) was part of the Riau Archipelago prior to the Anglo-Dutch Treaty of 1824. The Riau-Lingga Sultanate was established in the Riau islands during the first half of the $19^{\text {th }}$ century. Riau-Lingga served as an important part of many Malay kingdoms from the Srivijaya era up to the Anglo-Dutch Treaty of 1824. Riau was part of the Malacca Sultanate, until it fell to the Portuguese in 1511. Subsequently, Riau-Lingga came under the control of the RiauJohor Sultanate, which was established by Sultan Alauddin Riayat Shah II, in 1528. In 1722, a threat by Minangkabau outsiders to the unity of the newly founded Johor Sultanate was stopped with assistance from Bugis warriors (Watson Andaya, 1977). The war finished with the establishment of a dual-structured leadership between the Bugis immigrants and the indigenous Malays. The Bugis were honoured with the appointment as Yang di-Pertuan Muda (Deputy Ruler), which was the second rank in the kingdom.

This dual Riau-Johor Sultanate government was separated geographically, as well as, socially, and ethnically. It began in 1787, when the Malay Sultan chose to move to Daik on Lingga Island and soon after that, the Yang di-Pertuan Muda (hereafter, YTM) Raja Jaafar, also moved his seat from Ulu Bintan to Penyengat Island. By 1820, the Dutch had expanded their fortress in Tanjung Pinang, Bintan Island, and created a settlement there. Tanjung Pinang was the opposite of Penyengat Island, which served as the residence for the YTM. (Puten, 2007).

During the $18^{\text {th }}$ century, Riau-Lingga still enjoyed its status as a renowned trade route warehouse, between the Straits of India to China. Further, Riau-Lingga developed into a strong economic entity right up until the 1784 war, when it challenged and almost broke down the Dutch colonial centre in Malacca. Riau's eminence under YTM IV, Raja Haji Fisabilillah (1777-1784), with the advancement of trade and armed forces, gradually faded following his death in Teluk Ketapang (Putten and Azhar, 2007). After the failed attempt to regain control of the Strait of Malacca, Riau could no longer rely on its physical, and instead turn to diplomacy vis-à-vis the Dutch. The Dutch slowly increased their surveillance of Riau's vital trade links and gradually weakened Riau economy.

On 10 November 1784, a treaty was signed by the Dutch and Sultan Mahmud Syah III of the RiauJohor Sultanate. The treaty stated that all territories under this Sultanate belonged to the Dutch, and that they were on loan to Sultan Mahmud Syah III (Pusat Penelitian, 1977). In fact, Riau-Lingga's strategic location and tantalizing tropical natural resources tempted other foreigners to take control of it. For instance, the Dutch dominated the control over Riau's economy and monopolized its raw resources in an international market. From a geographical perspective, Riau was not easy to manage, as it was composed of many small islands. There were many complaints, from both the local inhabitants and the British, about the random actions of local leaders and pirates in Riau. Even though the Riau-Lingga Islands were problematic for the Dutch, their strategic location was potentially very beneficial, allowing them to keep a watchful eye on British influence in Sumatra (Putten, 1997). Later, the dispute between the Dutch and the British ended through a 'divide and rule' strategy.

During the early $19^{\text {th }}$ century, the Johor Sultanate was in complete disarray. Internal conflict and disunity led to the establishment of new dynasties. Intense foreign intervention in the Johor Sultanate could clearly be seen from the struggle for the throne between the two princes of Sultan Mahmud 
(1761-1812) (Junus, 2005). This alone, changed the Malay world's political map forever. Both the British and the Dutch aimed to monopolize trade and the economy, and subsequently installed their own choice of prince. In 1815, Tengku Abdul Rahman, backed by Yang Dipertuan Muda Raja Jaafar (1806-1831), was acknowledged by the Dutch as the new Sultan of the Riau-Johor Sultanate (Junus, 2002). Meanwhile, in October 1818, William Farquhar named Karimun Island as an appropriate central location for the British companies. However, Raffles preferred Singapore over Karimun Island, as the base of British colonies in the Malay world. By recognizing Tengku Husin as Sultan, this created opportunities for the British to gain control of Singapore. British immediately recognized Tengku Husain as Sultan in 1819. Concurrently, the Riau-Lingga Sultanate was established and subsequently separated from the Riau-Johor Sultanate for the first time. In February 1849, a treaty was signed between Raffles, Tengku Hussein, and Temenggung Abdul Rahman. The British agreed to pay around $\$ 5,000$ annually to Tengku Husein, and $\$ 3,000$ to Temenggung, for the rights to open its trade colonies in Singapore (Pusat Penelitian, 1977).

It was also reported that the British tried to bribe Engku Puteri with $\$ 50,000$, as she was the holder of regalia and a key figure in legitimizing the appointment of a Sultan (Junus). Meanwhile, in October 1822, the Dutch forcefully removed the regalia from Engku Puteri, and in November, Sultan Abdul Rahman was inaugurated by the Dutch using the seized regalia (Junus, 2005).

The Anglo-Dutch Treaty of 1824 drew a line of political division, where the integrity of the Sultanate was challenged by the foreigners. The British and the Dutch, without the presence of indigenous rulers (who were in fact the real rulers and owners of the land), determined their own territorial dominance, during a meeting in 1824. They divided the Malay world into two regions, destroying both the cultural and political unity that had existed for centuries. Accordingly, the Sultanate of Riau-Lingga was created under Dutch authority, and the Sultanate of Johor under the British. This intervention reflected the change of both political and economic realities, from that time until today.

Riau-Lingga was on the verge of becoming a leading seaport, and consequently, the main port for Southeast Asia trade. However, continuous conflicts and British interference, made Singapore eclipse Riau as a regional trade center. In June 1819, the population of Singapore rose from 150 to 5000 . In 1820 , it had reached 10,000, with trading outputs of around 4 million dollar (Junus). The rivalry between the British and the Dutch became more intense with the advent of Singapore as a British colony, during the first half of the 19th century. Frustration drove the Dutch to declare Riau as a free trade port in April 1828 to outperform Singapore as the busiest seaport in the region, but to no avail (Junus).

The intermarriage of the Malay and Bugis nobilities became the Dutch pretext to not appoint a new YTM after the YTM X Raja Muhammad Yusuf had died. The dualism of government i.e., the office of Sultan and YTM, ended in 1885, when Abdulrahman Muazzamsyah, the son of YTM X, Raja Muhammad Yusuf, was inaugurated as the new Sultan of Riau-Lingga (Putten, 1997). After his father died in 1899, with no successor, the Sultan left the palace in Lingga, which was established by the former Sultan, and moved to his father's palace in Penyengat. Unfortunately, the chosen successor (Raja Ali Kelana) was reluctant to succeed as per the decree of September 1900. Moreover, the political treaty of 1905 abolished the YTM position (Gordon, 1999).

The last Sultan had already faced the displeasure of the Dutch authority on several occasions. After holding two powers at one time i.e., Sultan and YTM, his shortcomings became evident. In 1903, he insulted the Dutch flag and was rude towards the Dutch residents. He was summoned by the Governor General in Batavia and was fortunate to receive a pardon. Nevertheless, he repeatedly showed unwillingness to cooperate with the Dutch government (Gordon, 1999). As a result, the Governor General signed a resolution on 3 February 1911. The resolution consisted of the deprivation of the Sultan, Tengku Besar of Riau (the crown prince and Rushdiah Club member), and its dependencies from their office. Monthly maintenance grants of 2,000 Rupiah for the ex-Sultan and 400 Rupiah for the ex-Tengku Besar were paid. The Sultanate was soon retracted by the Government by Ind. Stb. 1913, No. 19 (Gordon, 1999). Finally, in 1911, a huge number of Riau Malays, including Rushdiah 
Club members, migrated to Singapore believing that a great war was about to break out between the Dutch and Japan.

\section{Islam in Riau-Lingga}

The Riau-Lingga Sultanate adopted Islam as the foundation for governmental administration. During the $19^{\text {th }}$ century, the kingdom become the centre of Islam in the Malay world especially from 1804 , when Penyengat Island was bestowed by Sultan Mahmud to Raja Hamidah as her dowry. Thus, it played the role of more than just an administrative centre, but also as a prominent centre of Islamic scholarship and the mystical orders in the Riau-Lingga area.

The Bugis princes dominated the religious leadership of Riau. They were recognized for their patronage of ' 'ulamā' and support of reformist ideas. In Penyengat Island, YTM VI Raja Jaafar (18051831) invited qari (readers of the Qur'ān) and religious teachers from outside of Penyengat and gave them each an adequate salary. At least three periods of religious tradition in Penyengat can be described. First, during the early development of Penyengat Island, Muslim inhabitants believed in keramat. They used to pray at graves on the island (mainly at the graves of Raja Haji Fisabilillah, Engku Puteri, Raja Jaafar, and Habib Shaykh) (Hooker, 1989). Second, the period in which a more "pristine" Islam came to forbid grave worshipping and keramat beliefs. This began through the initiative of the pious YTM VII, Abdul Rahman (1831-1844), by building the now famous 'egg-white' Penyengat mosque. Soon, the mosque would unite the Muslim community in Riau in performing prayers, executing law, and managing the kingdom's administration.

Third, under YTM VIII, Raja Ali ibn Raja Jaafar's reign (1844-1857), Tarīqah Naqshabandiyyah made its way into the life of Penyengat Muslims; even all of the princesses in Penyengat studied mysticism. Before this, Tarīqah Khalwatiyyah and Sammaniyyah, brought by Abdul Ghafur from Madura, had thrived under YTM V Raja Ali's reign (1784-1805). They were well known as Marhum Pulau Bayan but were discontinued after his death (Matheson and Andaya, 1982). To reinforce the spiritual bonds between brotherhood members, twice-weekly meetings were conducted. Equally important, all staffs were ordered to learn the Qur'ān and about Islam. YTM VIII, Raja Ali ibn Raja Jaafar (1844-1857), was assisted by RAH. He also paid visiting scholars to teach them, such as Sayyid Abdullah from Bahrain. He forbade gambling, cock fighting, singing, and the playing of music instruments, and commanded the women to wear tudung (Matheson and Andaya, 1982).

The Tarīqah Naqshabandiyyah, which was transferred from West Asia by the mediator Shaykh Ismail of Makkah, was welcomed by YTM V, Raja Ali. Syaikh Ismail Minangkabawi, who at that time taught țarīqah in Singapore, was picked up by Raja Ali's royal boat (Gordon, 1999). Raja Ali and the royal families became Syaikh Ismail's murid (disciples), and twice weekly, performed the dhikr (remembrance of Allah) to gain spiritual experience. This tarīqah flourished under YTM IX, Raja Abdullah ibn Raja Jaafar (1857-1858), as this raja became the murshid (Sufi teacher) (Bruinessen, 1990). Subsequently, many works by Riaunese, tended to be of a tașawwuf (sufism) theme, and were in a style influenced by the tarīqah. Even though his reign was short (approximately one year), the writing development on syair about tașawwuf flourished; such as RAH's Thammarat al-Muhimmah (last part) and Syair Siti Sianah, and Raja Muhammad Tahir's Syair Pintu Hantu. Nevertheless, not all works were based on a tașawwuf theme. Raja Abdullah wrote syair on fiction like his Syair Qahar Mashyur, Syair Syarkan, Syair Incik Dusaman and Syair Madhi. Although YTM IX Raja Abdullah, became the murshid, the weird thing was the name of the YTM X Raja Muhammad Yusuf mentioned in the genealogy of this tariqah, instead of his name.

YTM IX, Raja Abdullah, was well known as a pious YTM. He was the first YTM to perform a pilgrimage to Makkah, after Raja Ahmad ibn YTM Raja Haji Fi Sabilillah. When he came back to Penyengat, YTM IX, Raja Abdullah, brought Shaykh Ahmad Jibrati and Tuan Syahabuddin ibn Shaykh Muhammad Arsyad Banjar with him (Sham, 1995). His decision to step down from the YTM position, after just one year of ruling Penyengat Island, was due to his intention to be alone, focused on prayer and becoming ahli $i b \bar{a} d a h$ (devout person). 
During its later development at the beginning of 1899, Islam in Riau-Lingga grew rapidly, especially through the existence of the Rushdiah Club. It was equally important, that even though the different religions of Riau inhabitants and the 'infidel' Dutch became a barrier, the development of Islam during the $19^{\text {th }}$ century, still continued, and was not hindered by the colonial government. Generally, Dutch colonialism was directed at political and economic measures, whilst socio-religious matters were left to the indigenous rulers.

That concept encouraged the implementation of a new strategy for dealing with the Muslim community, as developed by Het Kantoor voor Inlandsche zaken, as an institution established in 1899 with Snouck Hurgronje as its brain. He said that the actual enemy of colonialism was not Islam as a religion, but Islam as a political doctrine. In the field of pure religious performance (ibadah), the colonial authority must give Muslims freedom to perform their religious teachings. Whilst in political matters and state structure, the government must combat every endeavour that brings fanaticism, such as the spirit of Pan-Islamism in 1911, when Riau-Lingga was under the reign of the militant Sultan, Abdul Rahman Mu'azzam Syah (Sham, 1995).

\section{Education}

Education is a major criterion for evaluating the quality and capacity of civilization. During the early nineteenth century educational institutions such as mosques and pondoks, played important roles in disseminating Islamic knowledge. The culama $\bar{a}$ ' and educated people "graduated" from pondok or madrasah contributed significantly to the development of knowledge through writing. A considerable number of pupils attended Islamic schools. Although Riau-Lingga was not a famous religious teaching centre, like Kelantan and Banjarmasin, it had produced many intellectuals and prominent writers. According to Tuhfat al-Nafis, long before the education system was built by the Dutch, a traditional religious education system was already in place. We do not know where it was conducted, as there is no source available to tell us of the existence of madrasah or pondok during $19^{\text {th }}$ century Riau-Lingga. However, Abu Hassam Sham contends that the traditional teaching took place in the mosque and in the palace (Sham, 1993). There, students learned how to recite the al-Qur'ann, and read and write the Malay language, and $j \bar{a} w \bar{\imath}$ script. During that time, education still placed emphasis on religious knowledge, text, and literature; including the Arabic language. Many Arabic books, used for studying the Arabic language, tașawwuf (sufism), and ușül al-Dìn (theology), were used as teaching and writing resources. They used both kitāb (book) with their original language only and kitāb with a matn or Malay translation. Kitāb by local 'ulamā', such as Mir'at al-Tullab by Shaykh Abdul Rauf al-Singkel, was also used during the reign of Raja Jaafar (Sham, 1995). Haji Abdul Wahab, a Malay-Minangkabau native, was assigned to teach this book. The circulation of these Arabic books was supported by the visit of a West Asian 'ulamā' to Riau, some royal family who had performed pilgrimage to Makkah, and by gifts from neighbouring kingdoms.

During the early $19^{\text {th }}$ century, the colonial authority acknowledged their obligation to educate the indigenous population of the East Indies. For example, the Governor-General Herman Willem Daendels (1762-1818), published a decree in 1808, that the Regents must set up schools for the indigenous children and hire eligible teachers. However, it was not until 1818 that this decree was officially recognised under the Regering Regelement (Government Code of the Netherlands Indies). It asserted that the authority had the responsibility to provide indigenous children with schools, comparable to those received by European children (Moriyama, 2005). In 1833, a secular education system began through the establishment of a private school for Dutch children in Tanjung Pinang. Unfortunately, it closed in 1850, due to shortage of students (Pusat Penelitian, 1977).

The Provincial schools, known as regency schools (regentschaps-scholen), and subsequently renamed primary schools as lagere scholen, was a type of school which only provided an elementary education. Generally, there were only few students who attended this indigenous school. However, this form of education served a fertile soil for a modern readership, during the second half of the $19^{\text {th }}$ century (Moriyama, 2005). For instance, Sayyid Alwi al-Hādī attended a Malay School in Penyengat up to Standard III, before moving to Singapore and attending the Kampung Glam Malay School in 
1902(Gordon, 1999). Raja Muhammad Shafik, the son of Raja Umar ibn raja Hasan, the manager of Ahmadiah Press of Singapore, studied in Sekolah Rendah in Penyengat, under the Dutch. However, the Dutch education system did not easily take root in Riau because parents were opposed to sending their children to käfir (infidel) school. Consequently, the number of students remained low, and it was clear that the schools were not operating the way authorities had envisioned.

Kolonial Verslag also reported in 1880 that there were only three schools in Riau and East Sumatra for indigenous students. One was in Bengkalis (with 44 students), and the other two were in Tanjung Pinang and Lingga, with approximately 109 students (Pusat Penelitian, 1977). Schools were opened and strict regulations were drafted. However, the Dutch failed to attract local interest because parents were unaccustomed to this new type of institution, and favoured sending their children to pesantren or pondok (Islamic boarding school); generally, to recite the Qur'ān or read kitāb (religious texts). The secular and other modern types of education systems implemented in Riau, were reserved for a small number of native elites, particularly the royal family, nobility, the rich, and the children of Dutch officials. Many poor people chose to raise money to cover their living costs, rather than spend it on studying. That is why, during the early $19^{\text {th }}$ century, Riau-Lingga was characterized by a high rate of illiteracy, with only a few books printed in the Roman script, and a total absence of modern printing equipment.

The emergence of literacy promotes the culture of knowledge in any given society. Naturally, society, imbued by the culture of knowledge makes knowledge accessible to the public through library. In Riau, a library was built in Penyengat by YTM X Raja Muhammad Yusuf al-Aḥmadī (1858-1899). It provided a range of collections worth 10,000 Rupiah including various religious and secular books, local Malay books, and Arabic books from the heart of Islamic centres in Saudi Arabia, Egypt, Pakistan, and India. Some of the books were gifts from the al-Azhar University of Egypt or from other kingdoms (Sham, 1995). With help from the royal families who performed hajj, or merchants who often travelled to and from Makkah, Arabic kitābs were brought to Riau. Now some of the collection is still stored in the Yayasan Indera Sakti at Penyengat Island. This library is named Kutub Khanah Marhum Ahmadi (Hamidy, 2003a). Some of the library's collections were stored in the mosque. In 1982, a government project 'Reinvetarisasi Naskah-naskah Lama di Masjid Raya Pulau Penyengat', recorded that around 166 of the 326 copies, were preserved in the Penyengat mosque (Hamidy, 2003c). Once, a famous Indonesian scholar, by the name of Buya Hamka, visited Penyengat. He acknowledges that this library had expensive and valuable collections of various Islamic themes, such as fiqh, tafsir , tașawwuf, and philosophy. Some Arabic books, imported from West Asia such as Ihya' 'Ulüm al-Dīn (al-Ghazali), Al-Qanūn al-Tīb (Ibn Sina), and al-Zawājir (Imam Ibn Hajar), could be found there (Sham, 1995). This collection was accessible to the inhabitants who knew Arabic.

Apart from this library, there were other libraries belonging to rich and learned individuals i.e., Abu Muhammad Adnan's library in Penyengat (Ming, 2003). These libraries were used for Rushdiah Club research activities and knowledge enhancement, before they began writing. Indeed, religious education and good libraries, helped to produce great Riau Muslim scholars, and fostered excellent writing tradition for both Islamic and secular works.

\section{Writing Culture}

The Sultan and the YTM of the Riau-Lingga Sultanate paid special attention to the development of Islam, education, and writing culture. This facilitated the spread of reading and writing culture in the society. By embracing Islam, the Malays learned to read al-Qur'ān, which had significantly liberated them from illiteracy. Influenced by Islam, the Malay Muslims invented their own script, namely the Arab-Malay script (or $j \bar{a} w \bar{\imath}$ script), which later became one of the catalysts in their writing culture.

The writing culture developed rapidly during the time of YTM X, Raja Muhammad Yusuf (18581899). His long reign of 41 years was a productive period for RAH and the royal family, to produce many works, including syair and books (Andaya \& Matheson, 1979). RAH was a writer along with poet himself, and he provided the citizens the educational facilities they needed. YTM X Muhammad 
built a huge library, which have a very good collection of books. UU Hamidy (2003b) categorizes the writers from royal families before the $1890 \mathrm{~s}$, into four generations. The first generation was that of Raja Ahmad ibn YTM Raja Haji Fisabilillah (known as Engku Haji Tua). Born in 1773, he was the father of RAH. His syair was the famous Syair Perang Johor, Syair Engku Puteri, and Syair Raksi. The second generation included writers from the time of RAH, such as Raja Haji Daud (Syair Peperangan Pangeran Syarif Hasyim), Raja YTM VIII Raja Ali (Syair Nasihat), YTM IX YTM Abdullah (3 works), and Raja Zaleha (2 works). RAH wrote many pieces that were historically or religiously themed e.g., Gurindam Dua Belas, Tuhfat al-Nafis, Syair Kitāb al-Nikah, Muqaddimah fi intizām, etc. The third generation included writers from the time of YTM X Raja Muhammad Yusuf (1858-1899), including Raja Abdul Mutalib (2 works), Raja Hasan (Syair Burung), and Raja Safiah (Syair Kumbang Mengindera), etc. The final generation was noted by the early establishment of the Rushdiah Club (Hamidy, Teks 2003b).

Most of these writers were Bugisnese descendants, who came from intercultural marriages between Malays and Bugisnese. J Noordyun explained about the emergence of historical accounts in South Sulawesi, which is the Bugis homeland. Kings usually kept a diary, recording their experiences, such as births, deaths, wars, etc. This also encouraged the writing of Babad (Hamidy, 2003). The habit of diary writing in Bugisnese, and the reading and writing tradition using $j \bar{a} w \bar{\imath}$ script of the Malays united and brought a positive headway to the development of the Malay language and literature in RiauLingga.

The great attention given to writing activities by the kingdom did not necessarily limit or even dictate the works of writers, in terms of their content or writing style. They were given total freedom to write, if it did not bring harm to, or challenge the authority of the king, or deviate from Islamic values. Moreover, there was no possibility to contest the Sultan or YTM, because most of the writers were the royal family itself. To a lesser degree, there was an implicit challenge to Dutch authority, by expressing anger and grievances through their writings. This orientation of such writing's content began to emerge when there was no military strength left, to confront the Dutch in a real battle, after their failure in an attack on the Dutch-controlled Malacca, in 1784.

A transition period of literature development in Riau during the $19^{\text {th }}$ century brought changes to the disclosure of writer information, including his signature, published date, and location in the colophon. Previously, the writers' name, and when and where it was published, was never given (Putten \& AlAzhar, 1995). This was probably because writing was considered as a job confined to royalty, or people who were specially employed by the Sultan. Moreover, these writings were considered as properties of the kingdom, and no individual contribution was recognised.

Perhaps the growing attention from the Dutch, to the Malay language and literature, triggered a change. As a result, writing was no longer monopolized by the palace. Soon, having just taken control of the East Indies from the British during the $19^{\text {th }}$ century, the administrative government in Batavia and Den Haag realized that the knowledge of local languages and literatures was crucial. The Dutch government required a manual for the correct spelling of various vocabularies, in order to educate their officials and missionaries. Thus, they began to compile a Malay-Dutch dictionary. In addition, the Dutch authority established a department of indigenous affairs whose major aim was to compile materials of local Nusantara knowledge (Putten \& Al-Azhar, 1995). Later Residents Von Ranzow (1822-1826) successfully compiled a genealogy of the Riau royal family. Resident Elout (1826-1830) employed their scribes from the royal family, or even the common people of Riau-Lingga, to make copies of each Malay manuscript (Putten \& Al-Azhar, 1995).

\section{Conclusion}

Some Orientalists makes bold statement that before the advent of colonialism, this region was backward and regressive. Further, they claim that modernisation of society owed a lot to Western colonisation of this region. Such generalisation is problematic and an oversimplification of history. This is because even before Western colonisation, there was already great civilisations in the region. 
Similarly, Riau too had already experienced many remarkable achievements -politics, culture, education and economy - before the imposition of colonialism.. Despite Dutch colonisation, RiauLingga had continued to retain its cultural, educational and religious dynamism. Indeed, the kingdom had flourished in these spheres of human endeavours. Thus, this study demonstarates that depite the decline of political power, the Sultanate of Riau-Lingga during the early 19th century had continued to effloresce in terms of religion, education and writing culture.

\section{References}

Abu Hassan Sham. (1987). Pengarang-pengarang dari kalangan bangsawan keturunan Bugis di Riau. In S. H. Salleh (ed.), Cendikia Kesusasteraan Melayu Tradisional (pp. 178-212). Kuala Lumpur: Dewan Bahasa dan Pustaka.

Abu Hassan Sham (1993). Puisi-puisi Raja Ali Haji. Kuala Lumpur: Dewan Bahasa dan Pustaka. Abu Hassan Sham (1995). Syair-syair Melayu Riau. Kuala Lumpur: Dewan Bahasa dan Pustaka.

Andaya, B. W. (1977). From Rūm to Tokyo: The Search for anticolonial allies by the rulers of Riau, 1899-1914. Indonesia, 24, 123-156.

Andaya \& Virginia Matheson (1979). Islamic Thought and Malay Tradition: The Writings of Raja Ali Haji of Riau (ca. 1809-ca. 1870), in Perceptions of the past in Southeast Asia, edited by Anthony Reid and David Marr, Singapore: Heinemann.

Barnard, T. P. (1994). Taman Penghiburan: Entertainment and the Riau Elite in the Late $19^{\text {th }}$ Century. Journal of the Malaysian Branch of the Royal Asiatic Society, 67(2), 17-37.

Martin van Bruinessen (1990). The Origins and Development of the Naqshabandi Order in Indonesia. Der Islam, 67(1), 161-2

Gordon, A. (1999). The Real Cry of Sayyid Shaykh al-Hady with Selections of His Writings by His Son Syed Alwi al-Hady.Kuala Lumpur: Malaysian Sociological Research Institute.

Hamidy, U. (2003a). Bahasa Melayu dan Kreativitas Sastra di Daerah Riau. Pekanbaru: UNRI Press.

Hamidy, U. (2003b). Riau Sebagai Pusat Bahasa dan Kebudayaan Melayu. Pekanbaru: UNRI Press.

Hamidy, U. (2003c). Teks dan Pengarang di Riau. Batam: Cindai Wangi Publishing.

Ding, C. M. (2006). Wajah Terbuka dan Hidup Tertutup: Gender dan Seksualiti dalam Karya Sastera Melayu Riau Pinggir Abad ke 19. Sari, 24, 78

Hooker, V. M. (1989). Pulau Penyengat: Nineteenth Century Islamic Centre of Riau. Archipel, 37, 135.

Ishak, M. S. A. (1992). Malay Book Publishing and Printing in Malaya and Singapore 1807-1949 (Unpublished doctoral dissertation). University of Stirling, Scotland.

Jan van der Putten and Al Azhar (2007). Di dalam berkekalan persahabatan: Surat-surat Raja Ali Haji kepada Von de Wall, (Jakarta: Kepustakaan Populer Gramedia, 2007), 1.

Junus, Hasan (2002). Raja Ali Haji budayawan di gerbang abad XX. Pekanbaru: UNRI Press.

Mikihiro Moriyama, Sundanese print culture and modernity in $19^{\text {th }}$ century West Java. Singapore: Singapore University Press.

Munawwir, A. W. (2002). Kamus al-Munawwir Arab-Indonesia Terlengkap. Surabaya: Pustaka Progressif.

Pusat Penelitian Sejarah dan Budaya (1977). Sejarah daerah Riau: Proyek penelitian dan pencatatan kebudayaan Daerah. Jakarta: Departemen Pendidikan dan Kebudayaan,

Proudfoot, I. (1993). Early Malay Printed Books: A Provisional Account of Materials Published in the Singapore-Malaysia Area up to 1920, Noting Holdings in Major Public Collections. Kuala Lumpur: University of Malaya.

Putten, J. V. D. (1997). Printing in Riau: Two Steps toward Modernity. Bijdragen tot de Taal-, Landen Volkenkunde, 153(4), 717-736.

Putten and al-Azhar Eds. (1995) Di dalam berkekalan persahabatan. Leiden: University of Leiden. 